\title{
TRADISI JUAL-GADAI-WARISAN POHON JAMBU AIR (Strategi Bertahan Hidup (Life Survival Strategy) Masyarakat Desa Taddan, Sampang-Madura)
}

\author{
Abrorinnisail Masruroh ${ }^{1}$, Mauliadi Ramli ${ }^{2}$ \\ ${ }^{1}$ Program Studi Sosiologi, Institut Agama Islam Negeri, Madura \\ ${ }^{2}$ Program Studi Sosiologi, Fakultas Ilmu Sosial, Universitas Negeri Makassar \\ fnisya.orin@gmail.com ${ }^{1}$, mauliadiramli21@gmail.com ${ }^{2}$
}

\begin{abstract}
ABSTRAK
Penelitian ini bertujuan untuk mengetahui strategi bertahan hidup dengan memanfaatkan dan mengandalkan pohon jambu air oleh masyarakat Desa Taddan, Sampang Madura. Jenis penelitian ini adalah kualitatif deskriptif. Teknik dalam menentukan informan menggunakan purposive sampling, dengan kriteria yaitu masyarakat yang pernah melakukan atau terlibat dalam tradisi jual,gadai, dan warisan tanaman jambu air di Desa Taddan Sampang Madura. Teknik pengumpulan data yang digunakan yaitu observasi, wawancara, dan dokumentasi. Teknik analisis data kualitatif deskriptif melalui tiga tahap yaitu reduksi data, penyajian data dan penarikan kesimpulan. Teknik pengabsahan data menggunakan membercheck.Hasil penelitian ini menunjukkan bahwa, Sebagai sentra penghasil salahsatu komuditas buah jambu air, Ditengah keterbatasan ekonomi, masyarakat Desa Taddan menerapkan beberapa strategi bertahan hidup (mekanisme survival) yaitu dengan memanfaatkan dan mengandalkan hasil panen buah pohon jambu air.Tak hanya untuk dijual, tetapi juga pohon jambu air menjadi barang gadai ketika mereka terdesak untuk memenuhi kebutuhan ekonominya, dan juga menjadi harta warisan ke generasi selanjutnya.
\end{abstract}

Kata Kunci : Strategi Bertahan Hidup , Petani Jambu Air

\section{ABSTRACT}

This study aims to determine the survival strategy by utilizing and relying on water guava trees by the people of Taddan Village, Sampang Madura. The kinds of this of research is descriptive qualitative. The technique in determining informants uses purposive sampling, with the criteria that the community has ever done or involved in the tradition of selling, pawning, and legacy of water guava plants in the Village of Taddan Sampang Madura. Data collection techniques are observation, interviews, and documentationdescriptive qualitative data analysis techniques through three stages, namely data reduction, data presentation, and conclusion. The data validation technique is using a member check. The result of this study shows that, as a center production of one of the water guava fruit commodity, amid economic limitations, the people of Taddan Village implement several survival strategies (survival mechanisms) by utilizing and relying on the yield of water guava trees. It is not only for sale but also for water guava trees to become pawning goods when they are recessive to meet their economic needs and become an inheritance to the next generation.

Keywords: Survival Strategy, Water Guava Farmers

\section{PENDAHULUAN}

Kemiskinan merupakan fenomena yang sering dijumpai pada negara berkembang. Masalah ini kerap menjadi penghambat proses pembangunan karena mempengaruhi perkembangan sumber daya manusia (SDM). Umumnya, ini juga berbanding lurus dengan kondisi pembangunan dan pendidikan suatu daerah, seperti halnya yang terjadi di Sampang, Madura. Tak hanya sebagai salah satu daerah 3T (tertinggal, terdepan, dan terluar), Sampang juga masih menduduki peringkat teratas angka kemiskinan di Jawa Timur. Berdasarkan data Badan Pusat Statistik (BPS), jumlah penduduk miskin pada tahun 2017 mencapai angka 225,13 ribu jiwa atau sekitar 23.56\%. Pun demikian di tahun 
berikutnya (2018) yang hanya mengalami penurunan hingga angka 204,60 ribu jiwa penduduk atau sekitar 21.21\% (Statistik, 2017).

Secara definitif, BPS mendefinisikan kemiskinan sebagai ketidakmampuan individu dalam memenuhi kebutuhan dasar minimal untuk layak hidup. Atau dalam bahasa lain dapat diartikan sebagai sebuah kondisi kehidupan yang berada di bawah garis nilai standar kebutuhan minimum. Yang dimaksud garis kemiskinan di sini adalah sejumlah rupiah yang diperlukan oleh setiap individu untuk dapat membayar setiap kebutuhan makanan setara 2.100 kilo kalori per orang/hari, serta kebutuhan non-makanan yang terdiri atas perumahan, pakaian, kesehatan, pendidikan, transportasi, serta aneka barang dan jasa lainnya.

Sedangkan secara sosiologis, kemiskinan sendiri sebenarnya tidak selalu identik dengan kontur masyarakat pedesaan, karena nyatanya kajian ini mencakup bagian dari suprastruktur yang luas (Hermawati et al., 2015), (Zulfaira, 2012). Di perkotaan, tak bisa dimungkiri bahwa kemiskinan juga sangat nampak dengan adanya kesenjangan sosial dan tingginya angka pengangguran. Belum lagi jika dihadapkan pada masalah sanitasi, wilayah kumuh, hingga tingginya angka kriminalitas. Berbeda halnya dengan di pedesaan, khususnya di Desa Taddan, Kecamatan Camplong - Sampang, di mana masyarakat miskin umumnya bekerja di bidang pertanian dengan penghasilan yang minim dan stagnan. Tentunya, ini menuntut mereka untuk menerapkan berbagai strategi bertahan hidup (Life Survival Strategy) di tengah kemiskinan yang melanda.

Secara umum, strategi bertahan hidup atau mekanisme survival dapat didefinisikan sebagai kemampuan seseorang dalam menerapkan seperangkat cara untuk mengatasi berbagai permasalahan yang melingkupi kehidupannya. Ada beberapa konsep teori yang dapat digunakan untuk menganalisa masalah yang berkenaan dengan mekanisme survival, di antaranya adalah yang dikemukakan oleh James Scott dan Clark.

James Scott menyatakan ada tiga cara yang dilakukan masyarakat miskin untuk bertahan hidup, yaitu: 1) Mengurangi pengeluaran untuk pangan dengan jalan makan hanya sekali sehari dan beralih ke makanan yang mutunya lebih rendah; 2) Menggunakan alternatif subsistem yaitu swadaya yang mencakup kegiatan seperti berjualan kecil-kecilan, bekerja sebagai tukang, sebagai buruh lepas, atau melakukan migrasi untuk mencari pekerjaan. Cara ini dapat melibatkan seluruh sumber daya yang ada di dalam rumah tangga; 3) Meminta bantuan dari jaringan sosial seperti sanak saudara, kawan-kawan sedesa, atau memanfaatkan hubungan dengan pelindungnnya (patron), di mana ikatan patron dan kliennya merupakan bentuk asuransi di kalangan petani. Patron dalam kehidupan petani adalah pemilik modal tempat petani bekerja yang umumnya dapat membantu kesulitan keuangan yang dihadapi petani(Scott \& Basari, 1981).

Clark dalam (Suyanto, 1996) upaya seseorang memperbaiki kondisi perekonomiaannya memang selalu berhubungan dengan strategi-strategi yang dilakukan. Strategi tersebut bisa berupa, pertama; pertukaran timbal-balik berupa uang, barang dan jasa untuk mempertemukan kebutuhan sehari-hari dan kebutuhan mendadak. Di mana pertukaran ini juga berhubungan dengan jaringan sosial, entah melalui kerabat, tetangga, rekan kerja (informal social support networks), atau lainnya. Kedua, dengan menganekaragamkan sumber usaha atau sumber penghasilan, misalnya mencari pekerjaan sampingan di sektor informal, membuka usaha kecil-kecilan, menyewakan sebagian kamar rumah yang dimiliki atau lainnya.

Sebenarnya, penjelasan Clark tak jauh berbeda dengan Scott. Bedanya hanya terletak pada poin pertama, yakni dengan mengikat sabuk lebih kencang atau dalam bahasa sederhananya hidup lebih hemat. Menurut Clark, cara ini memang cukup efektif untuk 
jangka pendek, sedangkan untuk jangka panjang atau ketika krisis berlarut-larut, cara ini tidak cukup efektif sebagai strategi bertahan hidup. Karenanya, menurut Clark, mencari pekerjaan sampingan serta memanfaatkan jejaring jauh lebih efektif sebagai peredam selama krisis.

Hal serupa juga pernah dijelaskan oleh Clark dalam (Widodo, 2009), yang menyatakan bahwa terdapat beberapa strategi yang dapat dilakukan oleh rumah tangga miskin pedesaan antara lain: (1) melakukan beraneka ragam pekerjaan meskipun dengan upah yang rendah, (2) memanfaatkan ikatan kekerabatan serta pertukaran timbal balik dalam pemberian rasa aman dan perlindungan, dan (3) melakukan migrasi ke daerah lain sebagai alternatif terakhir apabila sudah tidak terdapat lagi pilihan sumber nafkah di desanya.

Berdasar pada SK Mentan No. 40/Kpts/TP.240/I/97 jambu air (Eugenia aquea Burm) merupakan salah satu buah unggulan Kabupaten Sampang dengan sentra produksinya berada di Desa Taddan dan sekitarnya (Kecamatan Camplong). Buah dengan ciri-ciri warna putih mengkilat, daging buah tebal, rasa manis dan segar, serta tidak berbiji ini, selain bisa dikonsumsi secara langsung, umumnya juga dibuat puree, sirop, jeli atau awetan lainnya. Bahkan, konon kulit batangnya juga dapat digunakan sebagai obat.

Tanaman jambu air ini dapat tumbuh dengan baik di daerah bercurah hujan rendah/kering sekitar 500-3000 mm/tahun karena cahaya matahari berpengaruh terhadap kualitas buah yang dihasilkan. Intensitas cahaya matahari yang ideal dalam pertumbuhannya adalah 40-80 \% dengan suhu 18-28oC dan kelembaban udara antara 50$80 \%$. Dengan kondisi tersebut, buah yang dihasilkan umumnya berkualitas baik dengan rasa lebih manis.

Tanaman ini sangat cocok untuk tumbuh di lingkungan tropis, pada tanah datar di dataran rendah hingga dataran tinggi dengan ketinggian mencapai 1.000 mdpl. Untuk media tanam, derajat keasaman tanah $(\mathrm{pH})$ yang cocok berkisar antara 5,5-7,5 dengan kedalaman kandungan air 0-50 cm; 50-150 cm dan 150-200 cm. Berikut informasi detail terkait buah jambu air khas Desa Taddan Kecamatan Camplong Kabupaten Sampang.

\section{Gambar. Detail informasi jambu air khas Kecamatan Camplong}

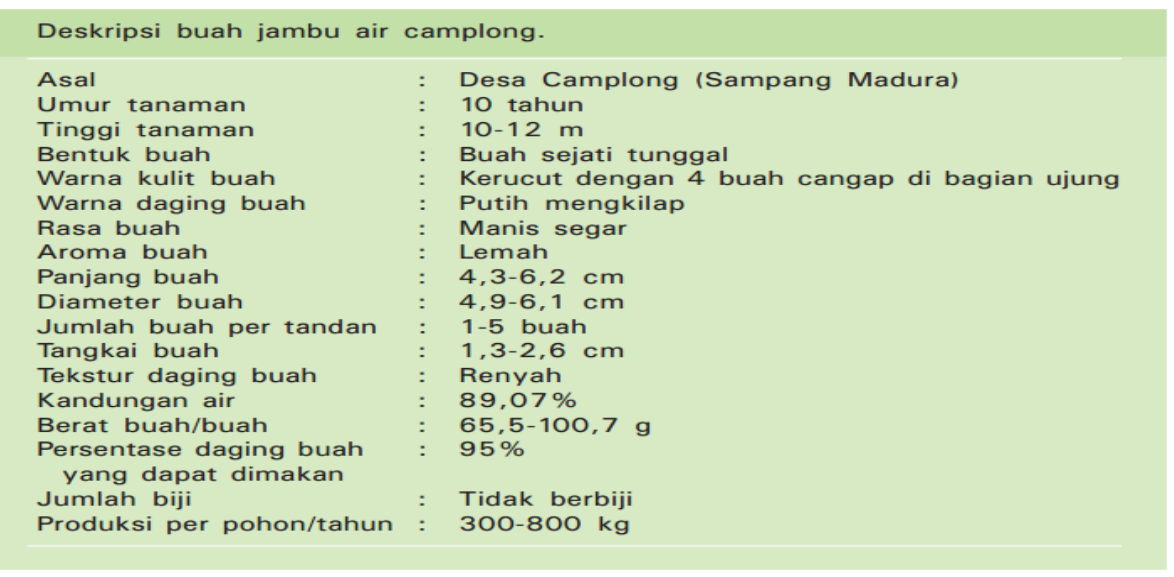

Sumber: Warta penelitian dan pengembangan pertanian, Vol 27 No. 52005

James Scott dalam teorinya yang mengulas mengenai teori mekanisme survival di kalangan petani (Ritzer, 2012) mengatakan bahwa individu ataupun kelompok pasti memliki kecenderungan untuk bertahan dari kondisi ataupun situasi yang tidak 
menguntungkan dengan cara melakukan bentuk mekanisme survival atau strategi bertahan hidup. Dalam teorinya, Scott menjelaskan bahwasannya dalam masyarakat miskin terdapat beberapa indikator sebagai upaya bentuk dari mekanisme survival yang dijalankan. Yang pertama, adalah terkait masalah bagaimana masyarakat bisa survive/bertahan dengan kebutuhan pangan yang ada. Menurut Scott, hal umum yang harus dilakukan adalah masyarakat tersebut harus mengurangi frekuensi konsumsi atau dengan mengurangi kualitas gizi makanan karena keterbatasan sumber daya yang dimiliki. Kedua, adalah dengan melihat keadaan lingkungan subsistem sekitar dan dapat mencari kegiatan ataupun pekerjaan yang sesuai dengan skill ataupun kemampuan yang dimiliki. Bisa dengan berjualan kecil-kecilan, bekerja sebagai tukang, buruh lepas, atau lainnya. Ketiga, adalah dengan jalan memanfaatkan pola pertemanan ataupun jaringan sosial sebagai sarana untuk menanggulangi kemiskinan yang tengah dialami. Analisis Scott di sini lebih ditekankan pada hubungan jaringan sosial yang sifatnya kekeluargaan sehingga bisa menimbulkan rasa aman dan ketenangan batin. Bisa juga hubungan antara patron-klien, di mana ikatan ini merupakan bentuk asuransi di kalangan petani (Scott \& Basari, 1981).

Satu hal yang cukup unik dan berbeda adalah cara masyarakat Desa Taddan menerapkan strategi bertahan hidup, yakni dengan memanfaatkan dan mengandalkan pohon jambu air. Bagi masyarakat setempat, pohon ini tidak hanya bernilai ekonomis karena buahnya yang bisa dijual, melainkan juga karena pohonnya yang bisa dijadikan barang gadai dan barang warisan. Jadi, mengingat nilainya yang sangat berharga tak heran jika hampir semua masyarakat desa memiliki pohon ini dan membudidayakannya. Sebuah hal yang cukup unik, di tengah kebiasaan mayoritas masyarakat Madura yang umumnya memiliki barang berharga atau investasi berupa sapi, tanah, kayu jati, dan emas. Tujuan penelitian ini adalah untuk menganalisa pola mekanisme survival atau strategi bertahan hidup masyarakat Desa Taddan dengan pendekatan teori tindakan sosial Max Weber.

\section{METODE PENELITIAN}

Penelitian ini menggunakan metode penelitian kualitatif dengan sifat penelitian deskriptif dan dibekali dengan pendekatan verstehen (pemahaman) dari Max Weber. Metode (pendekatan) ini digunakan guna menelisik penafsiran dan pemahaman dari serangkaian tindakan sosial. Secara sederhana, verstehen mengajak peneliti untuk menempatkan diri dalam posisi aktor dan berusaha memahami dunia sebagaimana yang dipahami aktor tersebut (Hardiman, 2003).

Penelitian ini dilakukan di Desa Taddan Kecamatan Camplong Kabupaten Sampang, dengan pertimbangan: Pertama, mayoritas masyarakatnya memiliki serta membudidayakan pohon jambu air sebagai komoditas unggulan Kecamatan Camplong. Kedua, masyarakat Desa Taddan memiliki tradisi unik menjadikan pohon jambu air sebagai barang gadai dan warisan. Ketiga, mayoritas penduduknya masih berada di bawah garis kemiskinan dengan mata pencaharian petani dan buruh galian batu.

Sedangkan subjek dalam penelitian ini adalah masyarakat Desa Taddan yang pernah terlibat langsung dalam proses gadai dan waris pohon jambu air. Dengan begitu, peneliti bisa mendapat gambaran nyata tentang bagaimana pohon jambu air bisa menjadi slaah satu strategi bertahan hidup masyarakat Desa Taddan. Penentuan subjek menggunaan sistem purposive, yaitu pemilihan ditentukan berdasarkan kriteria yang ditetapkan sebelumnya (Gunawan, 2013) yaitu masyarakat yang terlibat dalam tradisi jual beli, gadai dan warisan pohon jambu air di Desa Taddan Sampang Madura.

Teknik pengumpulan data menggunakan data primer dan sekunder. Untuk mendapatkan data primer, dilakukan dengan cara observasi dan wawancara. Teknik 
wawancara ini dilakukan dengan maksud mendapatkan data primer yang akurat dari sumber penelitian. Untuk mendapatkan data primer, peneliti akan melakukan wawancara mendalam (indepth interview) dengan berpedoman pada poin-poin yang ada dalam pedoman wawancara. Pedoman wawancara ini digunakan agar data terfokus pada topik yang hendak diungkapkan serta untuk menghindari terjadinya penyimpanganpenyimpangan yang tidak disadari (Ansori, 2014). Sedangkan untuk data sekunder, diperoleh peneliti melalui hasil-hasil penelitian-penelitian terdahulu, seperti jurnal dan hasil penelitian.

Selanjutnya, proses analisis data dilakukan dengan menelaah data yang tersedia, baik dari wawancara maupun observasi. Data yang sudah terkumpul akan diklasifikasi, dikategorisasi, diinterpretasi, dan kemudian dianalisis. Karena penelitian ini menggunakan kerangka teori Weber, maka kunci dari analisis data adalah proses verstehen (pemahaman). Melalui metodologis verstehen peneliti akan memahami makna subjektif tindakan-tindakan yang dilakukan subjek. Setelah proses verstehen maka akan dipilahpilah tindakan-tindakan yang dilakukan subjek dengan menempatkan klasifikasi empat tipe tindakan menurut Max Weber, diantaranya: tindakan rasional instrumental, rasionalitas berorientasi nilai, rasional bersifat afektif, dan rasionalitas bersifat tradisional. Kemudian, data tersebut akan disajikan dalam bentuk deskriptif naratif.

\section{HASIL PENELITIAN DAN PEMBAHASAN}

Desa Taddan merupakan salah satu desa di Kecamatan Camplong yang letaknya tepat di pesisir selatan Pulau Madura. Namun, meski tergolong desa pesisir, mayoritas mata pencaharian masyarakat setempat juga di sektor pertanian yang penghasilannya cenderung minim dan stagnan. Hal ini dikarenakan sektor pertanian yang hanya mengandalkan tadah hujan, serta belum adanya irigasi dan inovasi. Tak ayal, banyak dari mereka (dalam usia produktif 18-56 tahun) yang pekerjaannya tidak tetap atau serabutan. Entah itu menjadi kuli bangunan, buruh galian batu, atau membuka usaha kecil-kecilan di rumah. Sebuah cara atau strategi untuk mempertahankan hidup di tengah kondisi ekonomi yang serba terbatas.

Jika dianalisis lebih jauh, rendahnya pendapatan yang cenderung tidak menentu ini akan berujung pada sulitnya mengakses pendidikan dan kesehatan yang layak. Rendahnya pendidikan akan menyebabkan lemahnya daya saing dalam memperebutkan peluang pekerjaan yang lebih layak secara ekonomi. Tak berhenti di situ, tingkat pendapatan yang rendah ini juga akan menyebabkan kemampuan untuk melakukan akumulasi modal menjadi sangat terbatas. Karena umumnya, pada keluarga miskin, pendapatan sepenuhnya digunakan untuk memenuhi kebutuhan hidup rumah tangga. Keadaan inilah yang oleh Nurkse (dalam Kuncoro, 1997:132) disebut sebagai lingkaran kemiskinan.

Gambar 2. Klasifikasi Kesejahteraan Keluarga di Desa Taddan Kecamatan Camplong

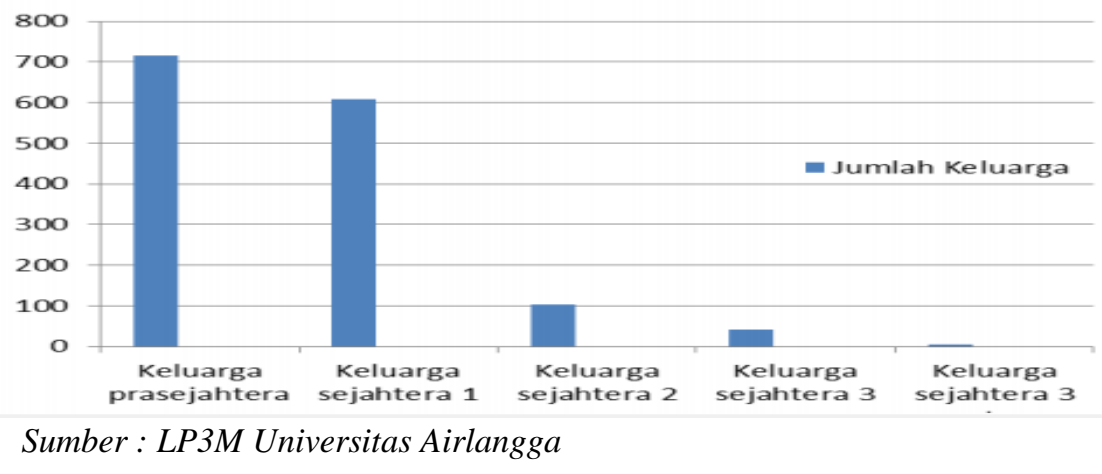


Jika mengacu pada data tersebut (2016), mayoritas penduduk Desa Taddan masih berada dalam kategori prasejahtera dan sejahtera 1. Artinya, jauh lebih banyak keluarga yang belum bisa memenuhi indikator "kebutuhan dasar keluarga" (basic needs) dibanding rumah tangga yang tergolong mampu. Indikator kebutuhan dasar keluarga sendiri meliputi kebutuhan akan sandang, pangan, papan, kesehatan, dan pendidikan. Atas dasar fakta itulah, penelitian ini berusaha menggali bagaimana mekanisme survival yang mereka lakukan.

Jika mengacu pada teori Scott, masyarakat Desa Taddan yang memang mayoritas berprofesi sebagai petani umumnya akan menerapkan strategi bertahan hidup dengan tiga cara, yakni: mengikat tali perut atau berhemat, mencari pekerjaan sampingan dengan memanfaatkan sumber daya yang dimiliki, dan memanfaatkan jejaring sosial. Pada masyarakat Desa Taddan, selain melakukan ketiga cara tersebut, terdapat cara atau strategi lain yakni dengan memanfaatkan dan mengandalkan kepemilikan pohon jambu air. Hal ini tidak lepas dari fakta bahwa Kecamatan Camplong termasuk Desa Taddan adalah penghasil utama buah jambu air. Uniknya, bagi masyarakat setempat, buah ini tidak hanya bernilai ekonomis karena bisa dijual, tetapi juga pohonnya yang bisa digadaikan ketika membutuhkan uang serta bisa menjadi barang warisan yang diturunkan ke generasi selanjutnya. Seperti penuturan salah satu informan, "Kalau di sini, pohon jambu air ini dijadikan warisan". Jadi, jika di daerah lain jambu air ini tidak mempunyai arti lebih selain buah, maka berbeda halnya dengan masyarakat Taddan yang menjadikannya salah satu harta yang berharga. "Bahkan jika disuruh memilih antara sapi dan pohon jambu, saya akan tetap memilih pohon jambu", tegas salah satu kepala keluarga di Desa Taddan karena menurutnya jika dilihat dari segi penghasilan, pohon ini lebih menguntungkan.

Berikut analisis strategi bertahan hidup masyarakat Taddan dengan memanfaatkan dan mengandalkan pohon jambu air.

\section{Menjual Buah Jambu Air}

Sebagai komoditas unggulan daerah, harga jual buah jambu air memang tergolong relatif tinggi jika dibandingkan dengan harga buah jambu lainnya, yakni dalam kisaran harga 500-1500 rupiah per buah. Harga ini bisa berbeda bergantung pada ketersediaan buah, apakah memenuhi permintaan pasar atau tidak. Jika sedang langka, harga bisa melambung tinggi hingga mencapai $2000 \mathrm{rupiah} / \mathrm{buah}$. Terkait hal ini, kondisi musim juga sangat berpengaruh. Pada musim penghujan, rasa dari jambu air tersebut cenderung kurang manis berbeda halnya dengan rasa buah pada musim kemarau yang jauh lebih manis dan segar. Selain itu, umumnya, permintaan pasar di musim penghujan terbilang lebih sedikit dikarenakan masyarakat cenderung menghindari mengonsumsi buah berair terlalu banyak. Meski demikian, pohon ini akan tetap panen di musim penghujan maupun kemarau, dan kemungkinan untuk gagal panen sangatlah kecil. Setidaknya, masyarakat Desa Taddan bisa tiga kali panen dalam setahun dan dijual per 100 biji kepada pengepul.

Berdasar pada fakta-fakta tersebut, tak heran jika mayoritas masyarakat setempat menjadikannya sebagai salah satu sumber penghasilan. Dengan perawatan yang tidak terlalu repot dan membutuhkan banyak biaya, pemilik bisa mendapatkan penghasilan sekitar 1.5 - 3 juta setiap kali panen dan dalam setahun bisa tiga kali panen.

Jika dianalisis menurut teori tindakan sosial Max Weber, maka tindakan masyarakat Desa Taddan ini tergolong pada tindakan rasional instrumental. Sebuah tindakan yang dilakukan untuk mencapai tujuan tertentu dengan mempertimbangan 
ketersediaan sarana atau media untuk mencapainya. Dalam hal ini masyarakat setempat bertujuan agar bisa mempertahankan hidup dengan memanfaatkan buah jambu air sebagai komoditas unggulan Kabupaten Sampang.

\section{Pohon Jambu Air Bisa Digadaikan}

Jika umumnya barang yang bisa digadaikan adalah barang berharga layaknya emas, rumah, tanah, dan lain-lain, maka beda halnya dengan masyarakat Desa Taddan yang memiliki tradisi menggadaikan pohon jambu air. Berdasarkan hasil wawancara, harga gadainya pun tidak tanggung-tanggung yakni bisa mencapai 1,5 juta sampai 10 juta. Dalam hal ini, harga sangat bergantung dari permintaan pemilik pohon jambu dan lokasi dari pohon tersebut. Jika pohon berada di area yang tidak terlalu banyak tersinari oleh matahari, maka hal ini dapat berpengaruh pada pertumbuhan sehingga harga bisa cenderung murah. Sebaliknya, jika pohon berada di area yang strategis dan cukup sinar matahari, harganya pun bisa semakin mahal mengingat pertumbuhannya yang baik dan cenderung berbuah lebat.

Untuk sistemnya, proses gadai yang dilakukan tidak memerlukan banyak persyaratan melainkan hanya berdasarkan kepercayaan (trust). Pemilik pohon dan pihak penggadai hanya membuat perjanjian secara lisan di awal dan tanpa adanya kontrak tertulis bermaterai.

Ketika seseorang memilih menggadaikan pohon jambu air dengan alasan untuk memenuhi kebutuhan hidup, tindakan tersebut dapat dikategorikan tindakan rasionalitas instrumental. Mereka memanfaatkan sumber daya yang dimiliki demi mencapai tujuan yang diinginkan. Di sisi lain, tindakan ini juga bisa dikategorikan rasionalitas nilai karena sebelumnya pasti telah mempertimbangkan nilai-nilai yang berlaku pada masyarakat setempat.

\section{Pohon Jambu Air Diwariskan}

Mengingat betapa berharganya pohon jambu air sebagai salah satu cara atau strategi bertahan hidup masyarakat Desa Taddan, maka umumnya mereka pasti memiliki lebih dari satu pohon. Bagi mereka, tindakan ini tidak hanya bertujuan mendapatkan penghasilan dari hasil penjualan buah atau gadai pohon, tetapi nantinya juga bisa menjadi barang yang diwariskan ke anak cucu.

Satu hal penting yang juga perlu dipahami di sini adalah meski tanpa adanya bukti tertulis kepemilikan, pohon jambu air yang dimiliki seseorang tidak akan pernah hilang karena diakui orang lain maupun tertukar dengan yang lain. Kepemilikan pohon bisa dibilang paten kecuali ada perjanjian gadai atau ada wasiat pewarisan. Bahkan, meski dalam kondisi pohon si A berada di tanah orang lain (misal saudaranya), pohon tersebut tetap menjadi miliknya. Misal ketika si B (Saudara si A) ingin membangun rumah di tanahnya yang sedang tumbuh pohon si A dan ingin menebang pohon tersebut, maka si B harus membeli pohon si A tersebut sebesar permintaan si A namun tetap dengan persetujuan si B. Aturan seperti ini ibarat sudah menjadi hukum adat masyarakat setempat.

Di sini jelas bahwa masyarakat Desa Taddan menerapkan tindakan tradisional. Sebuah tindakan yang dilakukan berdasar pada kebiasaan dan tradisi masyarakat setempat. Dalam artian, mereka melakukan suatu pengulangan atau hal yang dulunya telah pernah dilakukan sehingga sudah menjadi kebiasaan dan dianggap lumrah.

Teori tindakan sosial dari Max Weber yang berorientasi pada motif dan tujuan pelaku. Dengan menggunakan teori ini kita dapat memahami bahwa setiap individu maupun kelompok pasti memiliki motif dan tujuan yang berbeda terhadap sebuah tindakan yang dilakukan. Sebagaimana diungkapkan oleh Weber bahwa cara terbaik untuk 
memahami berbagai kelompok adalah menghargai bentuk-bentuk tipikal tindakan yang menjadi ciri khasnya (Tucker, 1965).

Weber mengklasifikasikan tindakan sosial secara subjektif ke dalam empat tipe, yaitu: Tindakan rasional instrumental, yaitu suatu tindakan sosial yang dilakukan untuk mencapai tujuan yang didasarkan pada pertimbangan dan ketersediaan alat/sarana untuk mencapainya; Tindakan rasional nilai yaitu tindakan yang didasari oleh kesadaran serta keyakinan akan nilai-nilai penting seperti etika, estetika, agama, dan nilai-nilai lainnya yang mempengaruhi tingkah laku manusia dalam kehidupannya; Tindakan sosial Afeksi, yaitu suatu tindakan sosial yang ditentukan oleh kondisi emosi, kejiwaan, dan perasaan aktor yang melakukannya; Tindakan sosial tradisional (traditional), yaitu tindakan sosial yang dilakukan berdasarkan pertimbangan kebiasaan, tradisi, atau adat-istiadat yang turuntemurun telah biasa dilakukan (Supraja, 2012), .

Keempat tindakan sosial tersebut menurut Weber akan mempengaruhi pola-pola hubungan sosial serta struktur sosial masyarakat. Konsep-konsep tersebut merupakan dasar, tetapi tidak mempunyai batas yang sama dengan pengertian Weber atas rasionalitas berskala besar. Teori tindakan sosial dari Max Weber ini dirasa relevan untuk menganalisis tindakan masyarakat Desa Taddan dalam upaya mengembangkan mekanisme survival sebagai tindakan sosial yang dilakukan untuk memenuhi kebutuhan ekonomi keluarganya. Apalagi, tindakan untuk menjual, menggadaikan, atau bahkan mewariskan pohon jambu air ini telah menjadi tradisi khas masyarakat setempat.

\section{PENUTUP}

Di tengah keterbatasan ekonomi dan fakta bahwa daerahnya merupakan sentra penghasil salah satu komoditas unggulan, masyarakat Desa Taddan Sampan Madura menerapkan beberapa strategi bertahan hidup (mekanisme survival) dengan memanfaatkan dan mengandalkan hasil panen pohon jambu air. Tak hanya untuk dijual, tetapi juga bisa digadaikan ketika kebuutuhan ekonomi mereka mendesak, dan pohon jambu air tersebut juga menjadi warisan untuk generasi selanjutnya. Sebuah tindakan yang menurut Weber mengandung motif-motif tertentu, yakni rasionalitas instrumental, nilai, dan tradisional..

\section{DAFTAR PUSTAKA}

Ansori, Y. (2014). Wawancara. Magetan.

Gunawan, I. (2013). Metode penelitian kualitatif. Jakarta: Bumi Aksara, 143.

Hardiman, F. B. (2003). Pustaka Filsafat Melampaui Positivisme dan Modernitas. Kanisius.

Hermawati, I., Diyanayati, K., Rusmiyati, C., Hikmawati, E., Andari, S., Winarno, E., ... Yulani, D. (2015). Pengkajian konsep dan indikator kemiskinan.

Ritzer, G. (2012). The Wiley-Blackwell encyclopedia of globalization. Wiley-Blackwell.

Scott, J. C., \& Basari, H. (1981). Moral ekonomi petani: Pergolakan dan subsistensi di Asia Tenggara. Lembaga Penelitian, Pendidikan dan Penerangan Ekonomi dan Sosial.

Statistik, B. P. (2017). Badan pusat statistik. Badan Pusat Statistik.

Supraja, M. (2012). Alfred Schutz: Rekonstruksi Teori Tindakan Max Weber. Jurnal Pemikiran Sosiologi, 1(2), 81-90.

Suyanto, B. (1996). Perangkap kemiskinan: problem dan strategi pengentasannya dalam pembangunan desa. Aditya Media.

Tucker, W. T. (1965). Max Weber's verstehen. The Sociological Quarterly, 6(2), 157-165.

Widodo, S. (2009). Strategi nafkah rumah tangga nelayan dalam menghadapi kemiskinan. Jurnal Kelautan: Indonesian Journal of Marine Science and Technology, 2(2), 150157.

Zulfaira, A. (2012). Analisis Penerapan Standar Masyarakat Miskin Di Bps Kotapekanbaru. Universitas Islam Negeri Sultan Syarif Kasim Riau. 